\title{
Applying the Role Drama Approaches of DIE in Teaching English Famous Play: Taking "The Cop and the Anthem" in a High School as an Example
}

\author{
Hsiao-hua CHANG (張曉華) \\ Professor of Department of Drama, Taiwan University of Arts, New Taipei \\ City, Taiwan \\ chang.hh@msa.hinet.net \\ Shan JING (单婧) \\ Teacher of English, The First High School of Weihai, Weihai City, Shandong, \\ China \\ shanjing25@gmail.com
}

\begin{abstract}
The teaching of famous English play is generally either for the comprehension of texts or a stage performance in our schools. While considering about an integrated curriculum of Drama and English could enable students to have a deeper, broader, more complete, and interesting course in the learning process, we designed and implemented a curriculum of Role Drama approaches of Drama in Education (DIE) into the teaching of an English play "The Cop and the Anthem" for the class of students who study English as a second language in a high school.

From observing participant students and evaluating the 5 -session teaching process in the class, we found that the effectiveness of the curriculum on Role Drama approaches of DIE not only lets students to have enjoyable English performing courses but also improves students' capabilities in English expression and personal literacy.

Depending in this teaching experience, finally, we present our conclusions on the feasibilities of activities for improving teaching.
\end{abstract}

\section{Keywords}

Drama in Education (DIE) - Role Drama approaches - The Cop and the Anthem English expression - personal literacy 


\section{Introduction}

\section{Study Background}

This case study is based on the research project of "Embedded classic reading to improve the high school English teaching system" for educational innovation in Shandong, China, 2021. Our research studies work for the Experimental teaching of an integrated curriculum of English and drama. Zhenhua Yu edited the English famous play and coordinated teaching matters, Hsiao-hua Chang designed the curriculum and compiled the research materials, and Shan Jing conducted the integrated teaching of drama and English in the classroom.

From the literature review, we found that one of the most noteworthy policies is the National Curriculum ${ }^{1}$ in British "Education Reform Act." Drama was placed into the English domain in 1992. Since then, English study was integrated with drama, and has become a standard course of the curriculum in England. The English study for Chinese students is different as China does not have such an educational policy. Besides, English is not the native language, and Chinese students take the course of English as the second language requirement in school. Generally, the teaching content is mostly about answering questions in the examination. Even if a teacher is willing to teach drama, most of them approach the teaching of English by way of a linear mode: straight to explain the context in the classroom or to perform the play on the stage in theatre. As a result, students are generally inadequate in listening, speaking, and expressing humanistic literacy.

In view of the fact that the integrated English course of drama can reinforce the current lack of learning in English, we designed the curriculum, "The Cop and the Anthem," by Role Drama approaches of DIE. We expected to prove whether this teaching method could benefit our Chinese students in English study.

\section{The Concept of Drama in Education}

Drama is integrated art form and can involve many elements to make a complete and harmonious performance. Basically, the drama in the pedagogical basis of DIE is a fundamental way to apply drama/theatre techniques systematically into teaching. It includes natural human spontaneous contact with others in a group, in which it is applied through the methods of creative drama, improvisation, role playing, imitation, and theatre game by the teachers or leaders in the structured teaching strategy. In the relationships of interactive learning, the participants can fully develop their imagination, express ideas,

1 See: Department for Education and Employment. 1999. p. 47-51. 
gain aesthetic experiences, and improve living skills. FitzGerald, M. defines DIE as (1990. p.4):

DIE is a workshop rather than a performance-based activity, drawn extensively from children's play. It allows participants to discover for themselves, through action and in the company of others, solutions to problems they encounter. The emphasis is on learning by doing, on experience and activity of the participants.

Since the teaching process of DIE is based on the characters in the structure of plot, and the teaching methods emphasize improvisational process, it has been also referred to as Curriculum Drama. Almost all the courses in the schools can be integrated with the DIE process, such as: languages, mathematics, social and natural sciences etc. With drama conventions in the teaching approaches, the teachers can lead the class to make up a story and to explore the theme and problem-solving, thereby developing the students' self-confidence, expressiveness, and social awareness. DIE itself refers to the integrated teaching that applying drama as a medium to deepen and broaden the subject to complete learning.

\section{Role Drama in DIE Teaching}

Role Drama approaches s one of the teaching methods of DIE. It was initialed by Carole Tarlington and Patrick Verriour in 199os. The teaching of Role Drama approaches sets up an imaginary situation, where students and teachers will participate in the expansion of events, issues and relationships as roles (Tarlington, C. and Verriour, P. 1991. p.9). It is in an action of the main characters that gradually reveal the meaning and value of a person's existence. Therefore, the main reason for using the Role Dama approaches in a play is that the character is the core of the drama. Evaluating a character's attitude and behavior while encountering various situations, incidents, or difficulties, often develops the basis for defining the individual's aesthetic value of life.

\section{The Pedagogical Basis of the Role Drama}

The integrated curriculum refers to a structure that conforms subjects with common attributes, forms, constructions, or related issues. Based on the Constructivism instructional design, Role Drama approaches teaching strategy adopts Jean Piaget's Cognitive-developmental theory on assimilation and accommodation. Through the active constructive function and the process of adjustment, the new awareness and information obtained are merged with the old knowledge to become the existing knowledge (Ref: Sigel, I. E. In Chang. 
S. C. p. 7) The constructivism teaching provides a Recursive Reflexive Design and Development model, with gradual steps to establish the understanding of contexts and the judgment for personality qualities.

\section{Role Drama for Learning Language}

In Role Drama approaches, a judicious selection of dramatic activities can certainly be used to reinforce particular items of vocabulary and structure for learning English, but their main advantage is in offering students the chance to move from controlled to free expression and to say something they really want to say (Maley A. and Duff, A. 1992. p.16). Ideally, by teacher's instruction which integrated within Role Drama approaches, the student not only could improve their proficiency in English expression but also through the protagonist of the drama in the action of a series of incidents, the life values that learners should recognize are gradually established. So that, in the future, the students could effectively and widely apply the knowledge and ability into their daily life.

In accordance with Tarlington and Verriour's Role Drama (1991), we designed the integrated curriculum of "The Cop and the Anthem" for five sessions of general narration, define the problem, develop the problem, solve the problem, and denouement on an action of the main character into the teaching process.

Here is the lesson plan and implementation on the curriculum for the play "The Cop and the Anthem" dependent in Role Drama approaches of DIE for 30 students in a class of the first grade in the First High School of Weihai in Shandong, China, as follows:

\section{Lesson Objectives}

"The Cop and the Anthem"

The aim of this curriculum is to apply Role Drama approaches into the play "The Cop and the Anthem" for studying English expression and to guide the students in thinking about a person's life value. From the teacher's explanation of the play about a homeless individual, Soapy, it guides the students to enter the drama situation, develop the related issues and realize the theme of this play.

In each session, the teachers and students could discuss and role-play the story to extend the situation of the characters and experience the mental journey of different characters in the designed dramatic activities. Through 
dramatic conventions (Neelands, J and Goode T. 2015) to work with the key points occurred in the plot, it is expected that the students could promote the capabilities in English expression and establish the proper values for life.

\section{Teaching Strategy}

1. Teacher leads the students to use English expression within the dramatic conventions of five-session to promote the interaction between individuals.

2. Through the Role Drama approaches, the teacher guides students to experience and recognize various viewpoints in order to create the actual concepts.

3. In the teaching process, the expression capabilities of English language and the values of a person's life are gradually established.

\section{Lesson Plan Framework}

"The Cop and the Anthem," originally is a short story by the United States author O. Henry published in December 1904. The play in our lesson has extracted the dialogue and edited it into an eight-scene script form; and then, based on Role Drama approaches, it is structured into a five-session process, as listed below:

The first session: general narration - Warm up exercise, presenting a story (explain the content of the course, discuss possible problems that may arise or develop, explain the rules of the game, let students discuss the problems in groups).

The second session: define the problem - Warm up exercise, the Role on the wall, the Collective role, feedback and summary.

The third session: develop the problem - Warm up exercise, Definition of space, Simulations, feedback and summary.

The fourth session: solve the problem - Warm up exercise, Sound-tracking, Small-group play-making, Still-image or tableaux, Thought-tracking, feedback and summary.

The fifth session: denouement - Warm up exercise, Follow up, This way/that way, Diaries letters journals, messages, feedback and summary. 
Key point

The First Session

The Second Session

The Third Session

The Fourth Session

The Fifth Session

$$
\text { indicate the problem }
$$

Define the Problem

Develop the Problem

Solve the Problem

Denouement
Key issues

Why is Soapy a homeless person?

What reason Soapy wants to go to jail?

What is the action that Soapy wants to take? What is an action of series of incidents that Soapy would take? How to solve Soapy's difficulties? What action should Soapy take? How should the best ending of the play be arranged?

\section{Distribution of Time}

5 periods, 5 omins per session

\section{Instructional Key Point}

1. Key question: What is the meaning of a person's life?

2. Drama materials: related pictures of people, places and incidents in New York City.

3. Focus issue: how to solve the dilemma of the main character.

4. The background of $5 \mathrm{~W} 1 \mathrm{H}$ :

Who: Narrator; 2 cops, Soapy, Gentleman, Waiter, Lady, Judge, Two strong men

When: Late of November

Where: Madison Square, Manhattan, New York City

Why: Why does Soapy want to go to prison?

What: What did Soapy do?

How: How will Soapy's situation develop? 


\section{Teaching Aids}

Colored markers and several sheets of poster paper

\section{Instructional Design and Implementation}

\section{Role Drama Approaches Instructional Procedure}

1. The first session: storytelling (1 period)

(1) Warn up exercises:

Handshakes (Ref. Maley A. and Duff, A.1992. p.39):

In pairs, partners stand facing each other. The object is to shake hands with partner without speaking, but with an appropriate facial expression (instructions may be given which involve a change inexpression, e.g. 'Each person you shake hands with is a very good friend' then change to 'you are at a very formal reception, you do not meet before' or you are just a girl/boyfriend with very good impression, etc. and then, change the partner continuing to greeting with the others).

Creating mirror images (Courtney, G. and Jossart, S.1998. p.14):

Partner stand facing each other. One is the leader, and the other follows the leader's actions. The pair then changes roles. In the following, change to a group of three or four, with one acting as a person, and the others to play the images in the mirror by different directions.

(2) General narration and indicate the problems

Key issues

1. Who: Soapy is Homeless?

Where: Madison Square Park

When: Night time

What: makes him a homeless?

Why: he would like to go Blackwell

Prison instead of the homeless

shelter?

\section{Dialogue content}

Scene 1. In the park

Narrator: Soapy has to sleep on the bench in the park at night. The wind blows hard and Soapy realizes it is time to make arrangements for his winter. 
Key issues

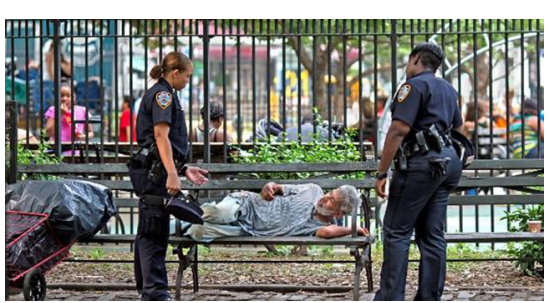

Picture taken from :

https://www.bing.com/images/

search? $q=$ the cop + and the an...

\section{Dialogue content}

S: Oh, what a cold night! I hate this dreadful weather. It's not necessary for a man to sleep in winter like a bear. I have to find somewhere warm. Blackwell Prison is a place where people are kind. It can receive anyone to stay for 3 months' even if he is a murderer. I'll try to get myself arrested so that I can enter the prison.

\section{Key issues}

2. Who: Waiter, Soapy

Where: an expensive restaurant at Fifth Avenue

When: Night time

What: Soapy takes an action?

Why: the waiter ill feeling on him?

\section{Dialogue content}

Scene 2. At the street

Narrator: Soapy left his bench, strolled out of the square and stopped at an expensive restaurant. It seems the restaurant is a good place to carry out his plan. 


\section{Key issues}
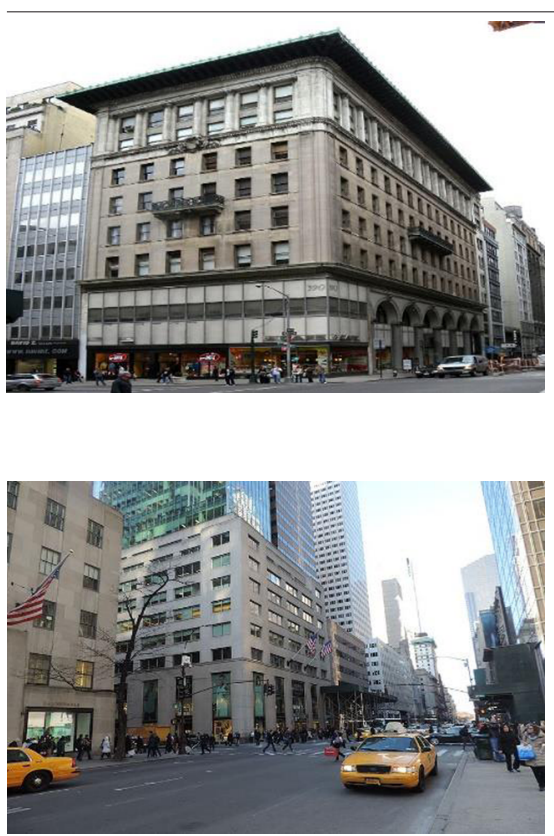

Soapy: (Looking confident in himself)

I was shaven, my coat was decent and I wore the neat a black tie. I'm sure the waiter will allow me to get in and dine there. I will order a roasted duck, a bottle of wine, a cup of coffee and cigar. After I get full, I will tell the waiter I have no money to pay the bill. Then I can be caught and happy to stay in the prison for the winter. (as Soapy set foot inside the restaurant door)

Waiter: No, no, no...I'm sorry, sir, I can't let you in.

Soapy: Why, I have money, you know... Waiter: Sorry... $。$

Sight of Fifth Avenue

Picture taken from : https://www.

bing.com/images/fifth+avenue\&form

\section{Key issues}

3. Who: Policemen, Soapy

Where: a fashion house at Fifth

Avenue

When: mid-night

Why: the policeman neglects the criminal?

\section{Dialogue content}

Scene 3. Outside a shop

Narrator: Soapy wandered along the Fifth Avenue. Suddenly the bright light and decent windows caught his attention. 
Key issues

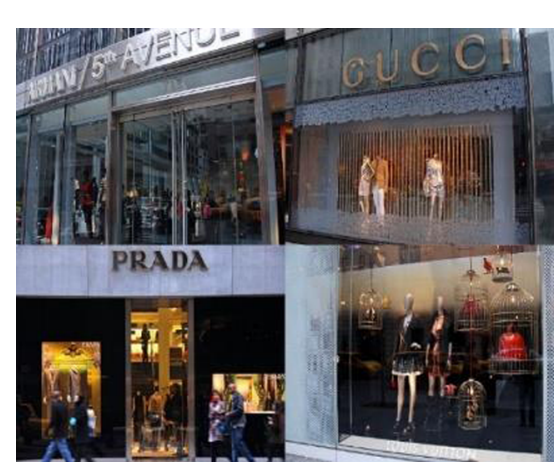

Picture taken from : https://www. bing.com/images/fifth+avenue\&form

\section{Dialogue content}

S: Oh, here's a shop. The shop window is large and bright. I know what to do. (He picks up a stone and throws it at the window. The window is broken. Then he walks about with his hands in his pocket and whistles) C1: (Running to the window) Hey! What's happening? Who broke the window?

S: Don't you figure out I might have had something to do with it? C1: What? You? You broke the window? $\mathrm{S}$ : Yes, of course, I broke the window a minute ago.

C1: Go away! What do you think I am? S: You are a policeman, and you should catch me. Because I broke the window. C1: What? Catch you? You must be mad. If you had done it, you would have run away. Get out of my way! (pushing him away)

S: (running after him) But I did it! I did it! (sighing) Oh, he is gone. It's no use. I have to try again.

4. Who: Soapy. Waitress Two strong Scene 4 . In the small restaurant men

Where: the small restaurant at Fifth Avenue

When: 9 o'clock in the morning Why: they throw him away?
W: Good morning, sir.

S: Good morning. W: Sit down, please. Here's the menu. What will you have? 


\section{Key issues}

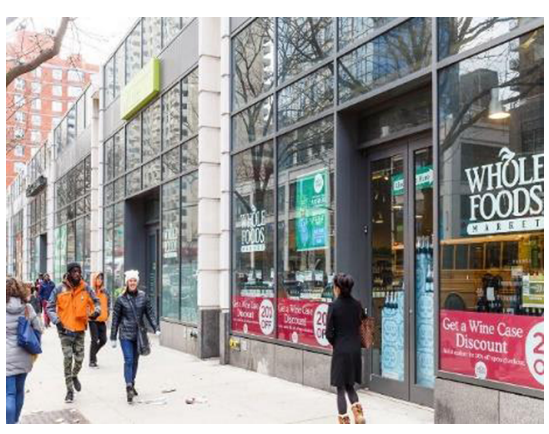

Picture taken from : https://www. bing.com/images/fifth+avenue\&form

\section{Dialogue content}

S: At first, I'd like a bowl of vegetable soup.

W: (writing down) A bowl of vegetable soup.

S: Then I'll have some steak and chicken. At last, I'll have a cup of coffee and a cigar.

W: Steak, chicken, coffee and a cigar. Er, excuse me, but this is a very big meal. Do you have enough money? S: What?! What did you say? Do you often ask such questions?

W: I'm sorry. I'll bring your food right away.

When Soapy eats up all his food.

$\mathrm{W}$ : Was everything all right, sir?

S: The food was very nice. I like it very much.

W: Thank you, sir. Here's your bill, sir. Twenty dollars, please.

S: Very well, but now, I want to tell you that I haven't twenty dollars. I don't even have a cent. Now, get busy and call a cop. And don't keep a gentleman waiting.

W: I see, will you come with me, please?

S: (standing up and following the waitress) 
Key issues

5. Who: Soapy. Lady, Policeman. Where: at 42 St. of Fifth Avenue When: At night What: happen?

Why: the lady replied in that way?

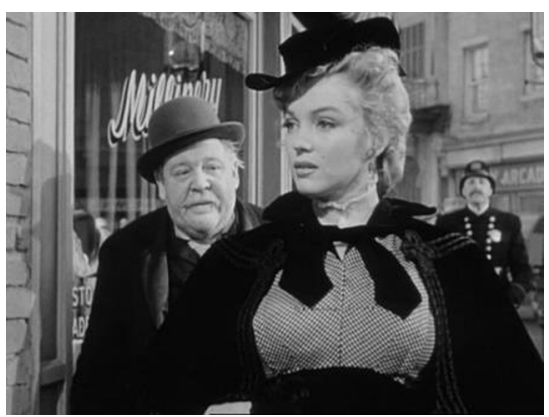

Picture taken from : https://www. bing.com/images/search?q=the cop+ and the an...
6. Who: Soapy. Gentleman, Policeman. Scene 6. In a cigar store Where: at E 14st. of Fifth Avenue When: At night

\section{Dialogue content}

Two strong men suddenly walk to Soapy, pitch him and throw him onto the pavement.

Scene 5. Offense a young lady Soapy walks boldly towards a young lady and tries to offense a young lady who is watching beautiful cups before a show window.

S : Ar there, Bedelia! Don't you want to come and play in my yard?

L: (joyfully) Sure, Mike, if you will buy me a glass of beer. I'd have spoken to you sooner, but the cop is watching. They walk arm in arm past the cop. Soapy is disappointed because he is still not arrested. At the next corner, he shakes off his companion and runs away.

Soapy sees a silk umbrella of a welldressed man by the door. He steps inside and takes the umbrella away. G: What are you doing? It's my umbrella. 


\section{Key issues}

Why : did this gentleman have a guilty conscience to let him take the umbrella?

7. Who: Soapy, Policeman

Where: Church at Fifth Avenue

When: At night

What: happen at Church

Why: did the policeman arrest him?

\section{Dialogue content}

S: Oh, is it? Well, why don't you call a policeman? I took it. Your umbrella. Why don't you call a cop? There stands one on the corner.

G: Well, you know how these mistakes occur---if it's your umbrella, I hope you'll excuse me. I picked it up this morning in a restaurant--If you recognize it as yours, I hope you'll--S: Of course it's mine.

Scene 7. In front of a church

Narrator: Soapy's several attempts to get arrested failed. Night falls. Soapy is disappointed. He decides that this year it will be impossible for him to get into jail, no matter how hard he tries. He wanders along the street until at last he finds himself standing in front of a church. From inside comes the sound of music. The choir is practicing a song for the coming Sunday. 


\section{Key issues}
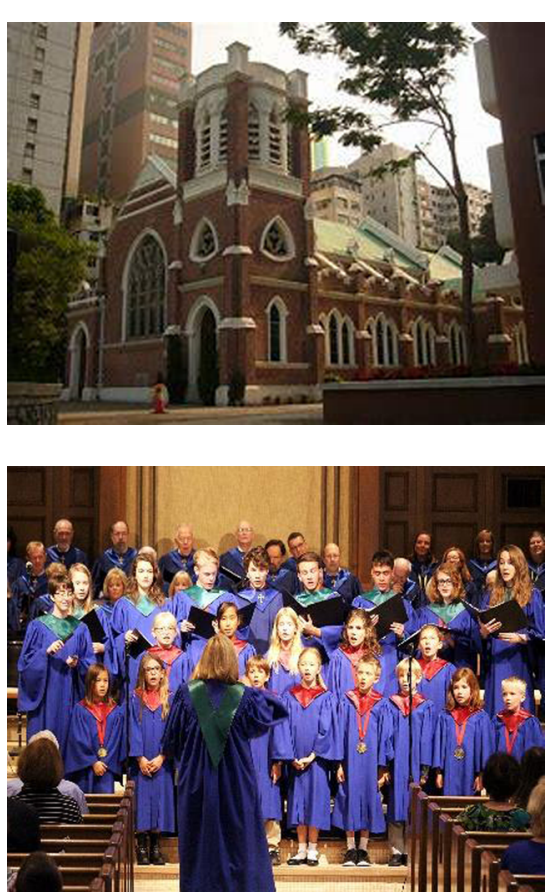

Picture taken from : https:// www.bing.com/images/ fifth+avenue+church\&form

\section{Dialogue content}

S: Such beautiful singing. It makes me forget all my problems. What is the name of the anthem? I used to sing it when I was a boy. How different my life was then. What's gone wrong? What did I do to let myself sink so low? Once I had great promise, but look at me now. My only aim is to get into jail. Well, I've got to change. I'm not an old man. There is still time to begin a new life. Only last week I was offered a job as a truck driver. I'm sure I can still have the job if I want it. I'll go to see about it tomorrow morning. I'll be somebody in the world, I will.... C : (laying his hand on Soapy's arm ). Hey you S: (looking quickly around) me? $\mathrm{C}$ : Yes, you! What are you doing outside this church? S: Nothing. Just listen to the anthem that the choir is practicing. $\mathrm{C}$ : Listening to the anthem?

S: I was walking by the church when I heard the song that we used to sing when I was a boy. I stopped to listen. That's all.

C: Oh sure. Well, you'd better come with me. The judge will be very interested in your story.

S: It's not a crime to listen to music, is it? 
Key issues

8. Who: Homeless. Policeman. Judge

Where: Criminal Court at Centre St.

When: At another day

What crimes did Soapy commit?

How: will he face this sentence?

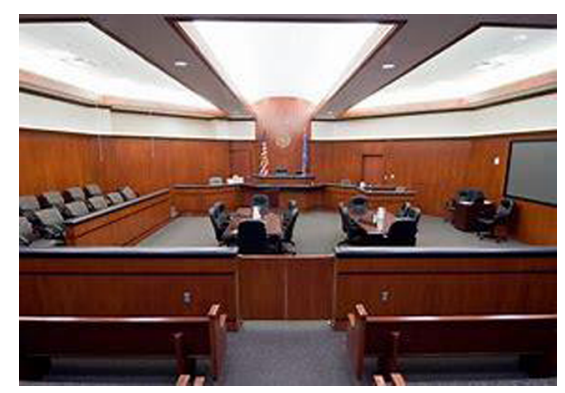

\section{Dialogue content}

C: No, not at all. If that's all, it isn't. But there have been some serious crimes in this neighborhood lately. Say! Didn't I see you earlier today? Of course! You are the one who was standing near that broken window on Fifth Avenue? I think you broke it after all. Come with me.

S: But officer.

C: Save your explanation for the judge. Come on.

Scene 8. To the court

J: All right. Next case.

C: Your honor, I found this man outside the church an hour ago. He said he was listening to the choir. But there's more to it than that. He's the same man I found in front of a broken window on Fifth Avenue this morning. $\mathrm{J}$ : Des the accused has anything to say for himself?

S: Well, your honor, everything the officer says is true. However, 


\section{Key issues}

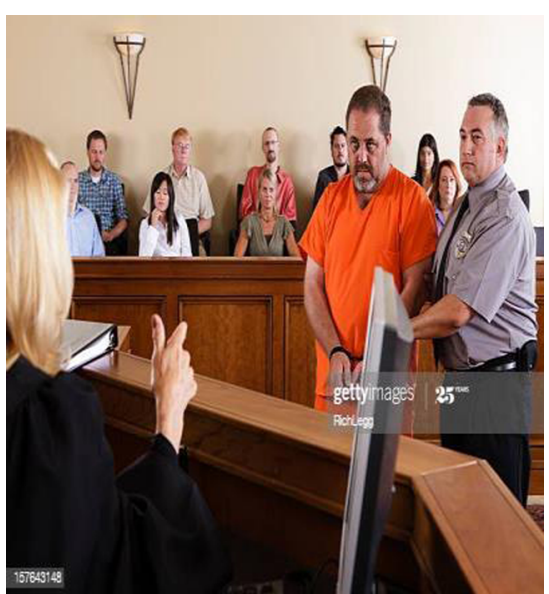

Picture taken from :

https://www.bing.com/images/

search?q=crimal + court $\&$ form

9. Follow up:

What would happen to Soapy if he were put in prison?

What would happen to Soapy after he leaves prison?

How: will he face this sentence?

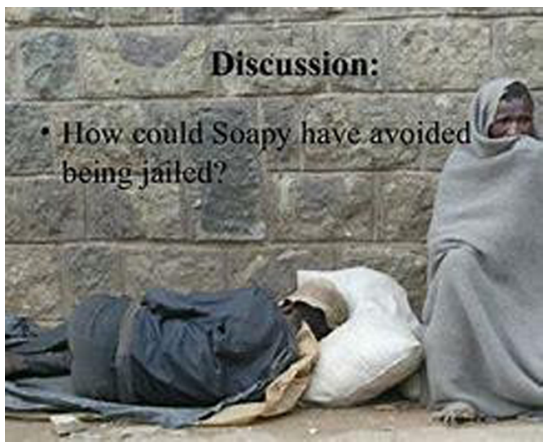

Picture taken from : https://www. bing.com/images/search?q=the cop+ and the an...

\section{Dialogue content}

J: If what the officer says is true and you did break the window, there is nothing more to say. Prepare to spend the next three months in jail.

The teacher guides the students to discuss and state their opinions. 
2. The second session: Defining the problem (1 period)

Character setting and problem development

Dramatic Activities

Warm up exercise

Role on the Wall

\section{Teaching content and procedure}

1. Quick Numbers (Spolin, V. 1986. p.26): The players form a circle and number off consecutively. Starts the game by calling another player whose number is called responds immediately with still another, and so on. 2. Quick Names: the rule as same as Quick Numbers.

Scene 1. In the park

Students divide into groups of six to eight, and they practice in groups on the content of the lines.

Define the role :

1. Character background setting: Suppose Soapy is a homeless, 35 years old.

2. Each group sends out a full-open paper, stick two pieces of paper together to form a long strip.

3. Ask a classmate as Soapy to lie on the paper, and trace drawing the figure with a marker on the paper.

4. Writing the description in the part of body. In the relevant parts of the body graphics, group members write down the person's behavior or state characteristics. It can also write down related social interpersonal relationships, such as bosses, colleagues, subordinates, classmates, competitors, etc. Love and hate things. Likes: gambling, alcoholism, singing, etc. Annoying, such as: going to work, social, getting up early, etc. 
Dramatic Activities

Collective Character

Feedback and summary
Teaching content and procedure

5. Ask each group member to take turns and introduce what the individuals have written.

1. According to the drawing and writing on the paper, each group should work out a 3 to 5 -minute content of performance about Soapy's life as a homeless from the past to the present. 2. Each group will assign roles according to the content of the plot discussed. Each member must play a different role, and perform impromptu rehearsal for dialogue with each other according to the characteristics of each character.

3. The groups take turns to perform. The teacher asks students to provide opinions on their performances, and to praise or comment on the students' performance in class. 
3. The Third Session: Develop the Problem (1 period)

From the development of a series of incidents to explore the problems in the plot

\section{Dramatic Activities Teaching content and procedure}

Warm up exercise

Defining space

Simulations
1. Greetings to each other:

(1) By pair, A say hello to the partner, then again louder, and then loudest. Role exchange, turns B to say again.

(2) Do the same way as before, but say hello with a complete the sentence.

2. Warm up with feeling (Ref: Jennings, S. 2010. p.47)

"I am angry because..." the partner will say, "you've lost your purse." Then the partner's turn start.

The students divided into groups of two to four, and one scene is selected from scene $2 \sim 6$ to practice. The teacher first reminds that each group of exercises must define the space:

Available props and furniture are used represent the place where a drama is happening; or fix the position and proximity of rooms, houses, places where events have taken place.

Each group will present the rehearsed scenes in turn, although the characters and scenes are fictitious, what needs to be emphasized is to connect the lines with the resources of daily life so that the performance would look like the real situation. 


\section{Dramatic Activities Teaching content and procedure}

Feedback and summery The teacher asks students to provide opinions on their performances, and to praise or comment on the students' performance in class.

4. The fourth session: Solve the problem (1 period)

\section{Dramatic Activities}

Warm up exercise

Soundtracking

Small-Group Play-making

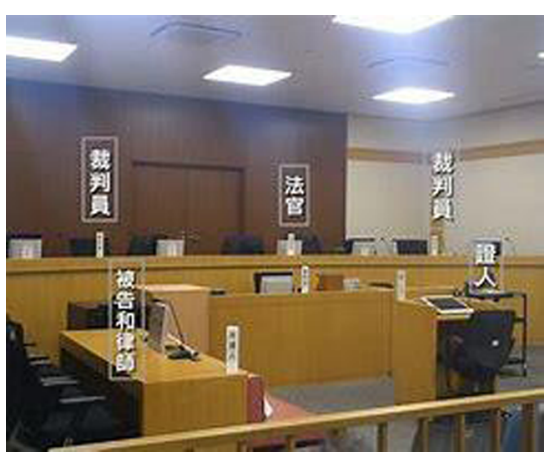

Teaching content and procedure

Transformation game (Ref: Spolin, V. 1986. p.42):

1. Space Shaping(solo):

Groups of two: actor and audience. By pair, player focuses on and plays with space substance, moving it about with hands, arms, and the whole body. Trying to let the audience to guess what is the object.

2, Shaping for team:

Team of three, four, five, or more could do the same way.

Scene 7. In front of a church

Realistic sounds accompany action. A team of students play the role as the singing of church choir accompanied Soapy's dialogue with the policeman until the end of this scene.

Scene 8. To the court

1. Divided the students to 4 or 5 groups, 6-8 members in a small group. 2. According to the lines in this Act, each group prepare and present improvisation as a means of representing a hypothesis, or to demonstrate alternative views of action. 
Dramatic Activities

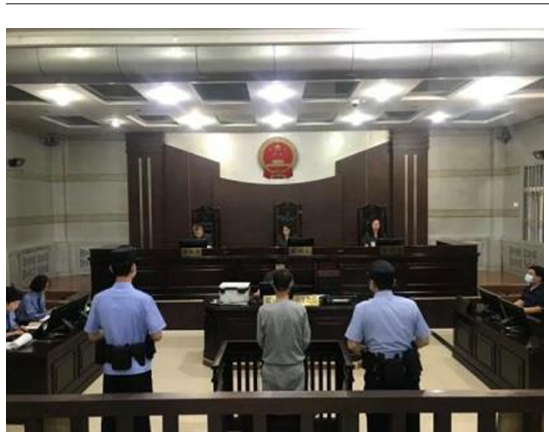

Picture taken from:

https://www.bing.com/ - Bing images

Still-image or tableau

Thought-tracking

Feedback and summery

\section{Teaching content and procedure}

3. Every student has to taking a role in the groups as the members of the court, include: judges, referees, defendants, lawyers, clerks, witnesses, victims and juries, etc.

Each group devises an image using their own bodies to crystallize a moment, idea or theme about the play. An individual act into concrete as sculptor to a group just as taking a photo picture.

Following the tableaux, the teacher ask the group keep still and invite the volunteers to choose a certain role, then pat him/her on the shoulder, and let the player simultaneously speaks the subtext of the role.

The teacher asks students to provide opinions on their performances, and to praise or comment on the students' performance in class. 
5. The fifth session: Denouement (1 period)

Dramatic Activities

Warm up exercise

\section{Teaching content and procedure}

1. Warm up with voice (Jennings, $S$. 2010. p.41):

(1). Make a "Hum" sound until your lips start to tingle, stopping and starting serval times.

(2). Make a "La" sound very quietly at first and then louder.

(3). Make a "buzzing" sound as a swarm of bees in the distance and getting closer and closer.

2. Three-way conversation (Spolin, V. 1986. p.133):

(1) Three seated players. One player $A$ is the center, the others B and C are the ends.

(2) Each end player chooses a topic in an act of this play and engages the center in conversation as if the other end player did not exist.

(3) The center player must converse with both ends, fluent in both conversations without excluding either end player. Focus for end players, is to hold a single conversation with center player only. 


\section{Dramatic Activities}

Follow up

This way/that way

Diaries, Letters, Journals, Messages

\section{Teaching content and procedure}

Groups of six to seven members. improvise a scene of Open-end what happen next after the teacher proposes the following sentences that the judge may make:

1. Serve three months in prison.

2.The penalty was three months of forced labor to repay the loss of the stores.

3. Release on bail and civil compensation of USD 5,000 for the total losses.

4. What would happen after he leaves prison?

This drama convention is used as to understand the positions and perspectives of different characters in the plot.

1. Teacher invites the students who playing the role of key figures, standing in different places of the classroom.

2. Let them individually state their views on the characters they have played.

3. Invite volunteers in the audience to stand beside the character he or she supports and describe the reasons. In different role positions, such as: Soapy, judges, police officers, shop assistants, etc., let students write a letter or use WeChat to inform one who your loved ones about your point of views.

Ask the volunteers to read aloud the letter they wrote. The teacher comments and encourages students what they have performed in this unit. 
Dramatic Activities

Feedback and summary
Teaching content and procedure

The teacher asks students to provide opinions on their performances, and to praise or comment on the students' performance in class.

\section{Teaching Processes Analysis}

After completing the five sessions of teaching in this course, the authors found that the Role Drama approaches can guide students to a deeper exploration and understanding of the text. The performance of students and the instruction of the teacher in this curriculum have confirmed the feasibility and necessity of DIE in the teaching of English courses. Here is a comprehensive analysis of the key points of the overall teaching process:

\section{The Role Drama Approaches is Very Well Integrated with English}

\section{Teaching in the Curriculum}

In the first session of general narration and indication of the problem, it is obvious that the students are looking forward to the character's future life, and they have been able to try to express their ideas in the English they have learned. S 21 said :

What is more distinctive is that it has extended a series of more in-depth content on the basis of English learning.

In the second and third session of define and develop the problem, based on the understanding of the role, the students rehearse the plot improvisationally. During the performance, the students have been able to deeply explore the connotation of the plot and the story and to present the character's mental journey. Just as S 21 said:

It was not just a reading practice in our daily English class. We paid more attention to the emotion of the character instead of the grammar and vocabulary.

In the fourth and fifth session of solve problem and denouement, there are many surprising performances, especially in the Fellow-up, where students 
explore the reasons why characters make different choices from different perspectives. $S_{3}$ said :

I like the part that we can act Soapy, it was so interesting!

Indeed, for Soapy's choices after being released from prison, each group has a different ending in the continuous recreation. The integrated curriculum gave the students the chance to role-play and increase the complete joyful English learning process.

The Role Drama Approaches can Successfully Achieve the Curriculum Teaching Goals

The two educational goals of this lesson: being able to express clearly and fluently in English and thinking about the value of one's life, both are clearly achieved in this curriculum. From the performances of each group of students, the teacher saw that the students could use English to express their understanding of the inner world of the characters, gave full play to their imagination, and solve problems with logical inferences. After playing the role of Soapy, a student $\mathrm{S} 16$ said:

It gave me more passion and desire to learn more. Also, we didn't just read the text, but we had the chance to imagine, to communicate, to direct our own ideas.

As the activities continue to explore and deepen, students' understanding of the text becomes broader. It even discussed the extended theme of "How can I live better in my life?"

The Bilingual Teaching in Both Chinese and English Makes the Interaction Between Teachers and Students More Fluent and

\section{Harmonious}

The student's language capability to adapt to Role Drama approaches is better than what the teacher originally expected. Although, in the early stage of second session, the teacher seemed a bit nervous and rushed the teaching. The main reason is that the teaching in class is conducted by the teacher totally speaking in English. Some students with weak listening ability fail to respond in time needed for the teacher to repeat the explanation to understand the teacher's intention. However, English is a second foreign language for our high school students. S 24 said : 
All in all, the class was good, it is not too boring, is not very exciting too. Because we spent much time in explanation, I hope that we can have more time to perform.

Therefore, the teacher made adjustments on the spot to supplement with Chinese, slow down the pace of explanations and increased the group discussions. In these ways, the teaching converted more fluid, and the students' performances also come to be more natural. S 16 said:

We were more like a group, discussing a question. We got the chance to say whatever we thought in mind in a relaxing way.

So that, students can understand the scenes they play faster and more clearly in the subsequent drama activities, the presentations of the characters, situations, events and stories appear to be much smoother. Since then, the relationships in discussion, interaction and performance between teachers and students have become more and more harmonious.

The Teaching Activities of Role Drama can Arouse More Diverse Cognition Among Students

The Role Drama approaches lead the text in a clear and rhythmic context. The students' expressions not only involve the characters in the story, but also extend to the social issue, and the warmth and cold of human relationship. Especially, during the sharing and summary in the last part of each session, there are always have some lively discussions. S 9 share his point of view:

For me, the most unique thing about this course is that we have the opportunity to write, direct and play our own plays. In the various class activities, our performance ability has also been trained.

Students can present their opinions and life choices in the activities, which makes them feel very useful in their daily life.

The Teaching Activities of Role Drama Approaches can Promote Students'Better Cooperation and Creativity

In each session of teaching, the teacher saw the students' curiosity and devotion to the characters, scenes, and plots. This experiential inquiry learning method has stimulated the cooperation and creativity of the students, allowing them to have more in-depth attention and thinking about the problems shown in the text. A student $\mathrm{S} 2 \mathrm{O}$ approved and said: 
Drama taught me to be calm, and also taught me how to get along with the people around me better. I will go forward bravely with love for this great art form.

Indeed, after the learning process of this course, the friendship between students has grown closer.

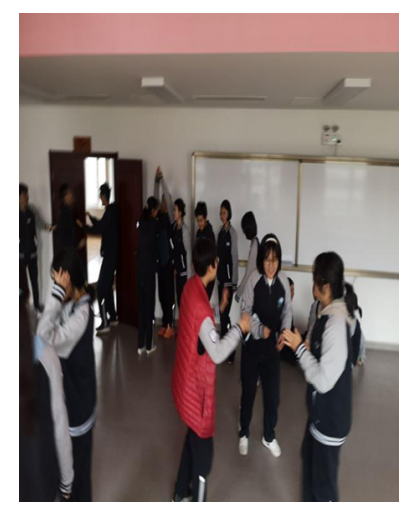

While student groups in discussion and rehearsal, the English teacher went to a group for assistant.

Photo by Yu, Zhenhua

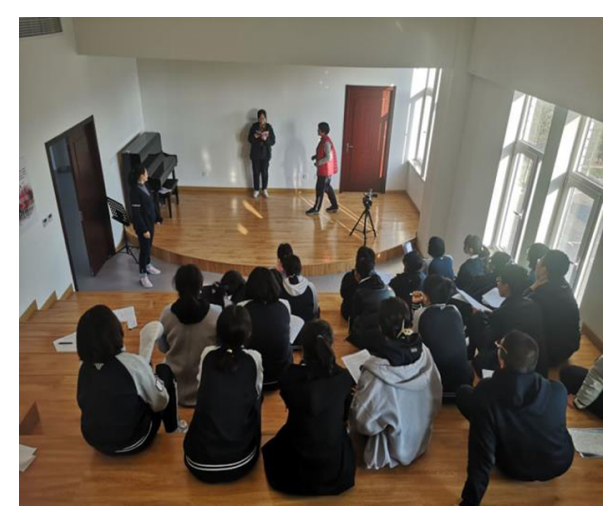

The student group take turns to perform their works in front of the classmates.

Photo by Yu, Zhenhua

\section{Teacher's Self-reflection on Teaching}

After the design and implementation of this lesson for 5 periods in one week, the review of the overall teaching is summarized as follows:

\section{1}

\section{Activity Design}

The selection of role drama approaches fits the characteristics of the text. During the development of the role-centered plot, discussions with students, rehearsal and sharing are carried out very smoothly.

\section{2}

\section{Teaching Content}

The teacher's guidance can help students understand more clearly the relationship between the script analysis and the characters. The activities and the information provided can encourage students to think more deeply. 


\section{$3 \quad$ The Student Learning Situation}

In a relaxed and happy atmosphere, students can cooperate seriously with each other, create their performances together, and share experiences with each other.

\section{$4 \quad$ Teaching Attitude}

At the beginning of the dramatic activity, the teacher had some doubts about whether the students could cooperate with the instructions. But with stepby-step guidance, the activities become more and more interesting. In general, the teacher can seriously explore, in-depth knowledge of relevant issues. Teachers always keep a high degree of interest in the subject that students are concerned about, and also maintain an open attitude to discuss any extended incidents.

\section{$6 \quad$ Teacher-student Relationship}

Except for the slightly restrained feeling at first, most of the teaching is harmonious and pleasant. Many excellent creative performances breakthrough form with repeated improvisational attempts.

\section{Conclusion}

In this case study of teaching English in a high school class, the activities of Role Drama approaches provide teachers with the lesson plan and implementation which allow students to spontaneously apply English to express their opinions and interpret the performance of different roles. It proved what the language educator J Stewig said:

"Spontaneous dramatics" to the language arts curriculum can provide the necessary opportunities for development of language and language related abilities (1973. p. 4).

This lesson plan and implementation have been tried out in the First High School of Weihai in Shandong Province, China. ACCording to to the teacher's response to the class, the learning atmosphere is enthusiastic. This is based on the learning of famous English plays to understand the theme of the role evaluation, and it could lead students to recognize the responsibilities for what has beensaid and done. It is just like a student, $S$ 1o's feedback:

In this class, I not only learned how to appreciate this elegant art form, 
but also became a real actor, playing different roles on the square inch stage and finding my true self in all the roles. The stage has taught me a lot, and our teacher also taught me how to perceive the real self and find my existence in the process of learning and performing.

From the above analysis, we can see the applications of Role Drama approaches of DIE in the second language teaching of famous play in the curriculum is not only for examination, it could let our Chinese student fulfill the practice, improve the student capability in expression with enjoyable surroundings, and promote qualities of personality. The achievement of the student performance in the class lets this drama teacher come to have great confidence in the English teaching.

\section{About the authors}

Chang, Hsiao-hua (張曉華), Professor of Department of Drama, National Taiwan University of Arts, New Taipei City, Taiwan (ROC). He obtained his MA degree from New York University in educational theatre program (1988) and has published seventeen books on Educational Drama/Theatre as well as over 5o peer-reviewed articles. He continues to pursue his research to support the field of Drama Education and Therapy in Taiwan or mainland China.

Jing, Shan (单婧), English Teacher of the First High School of Weihai in Shandong, Mainland China. She obtained her bachelor degree from Qufu Normal University in English teaching major. She also got the certificate of Career Management Tutor in 2015, she began to introduce drama elements into her English class and career management class. She also organized some drama workshops for children in junior schools and primary schools.

\section{Reference}

Chang, H. (张晓华)。（2004）。 《教育戏剧理论与发展》(The theories and development of Drama in Education)。Taipei：Psychology。台北：心理。

Courtney, G. and Jossart, S. (1998). Story drama. New Jersey: Good Year Books.

Department for Education and Employment (1999). "The National Curriculum." In Handbook for primary teachers in England. London: DfEE.

Neelands, J and Goode T. (2015). Structuring drama work (3rd ed.). Cambridge: Cambridge. 
FitzGerald, M. (1990) Australia, in Swortzell, L. Ed. International Guide to Children's Theatre and Educational Theatre. New York, Westport, Connecticut, London: Greenwood.

Jennings, S. (2010) Creative drama in group work (2nd ed.). Milton Keynes: Speechmark. Maley A. and Duff, A. (1992). Drama Techniques in Language Learning. Cambridge: Cambridge.

Sigel, I. E. (1978). Constructivism and teacher education. In Chang, S, C. (张世忠). Constructive instruction: Theories and applications 《建构教学: 理论与应用》(2000). Taipei: Wu Nan 台北：五南。

Spolin, V. (1986). Theater games for the classroom: A teacher's handbook. Illinois: Northwestern University.

Stewig, J. (1973). Spontaneous drama: a language art. Columbus: Charles E. Merril.

Tarlington, C. and Verriour, P. (1991). Role Drama. Portsmouth: Heinemann. 